\title{
1Detailed seismic imaging of Merapi volcano, Indonesia, from local 2earthquake travel-time tomography
}

3

4Mohamad Ramdhan ${ }^{\mathrm{a}, \mathrm{b}}$, Sri Widiyantoro ${ }^{\mathrm{c}, \mathrm{d}^{*}}$, Andri D. Nugraha ${ }^{\mathrm{c}}$, Jean-Philippe 5Métaxian ${ }^{\mathrm{e}, \mathrm{f}}$, Nicholas Rawlinson ${ }^{\mathrm{g}}$, Asep Saepuloh ${ }^{\mathrm{h}}$, Said Kristyawan ${ }^{\mathrm{a}, \mathrm{b}}$, Andry S. 6Sembiring ${ }^{\mathrm{a}, \mathrm{b}}$, Agus Budi-Santoso ${ }^{\mathrm{i}}$, Antoine Laurin ${ }^{\mathrm{e}}$, Ahmad A. Fahmi $^{\mathrm{e}}$ 7

8 ${ }^{\mathrm{a}}$ Study Program of Earth Science, Faculty of Earth Sciences and Technology, 9Institut Teknologi Bandung, Jalan Ganesa No. 10, Bandung 40132, Indonesia 10 Agency for Meteorology, Climatology and Geophysics, Jalan Angkasa I, No. 2, 11Kemayoran, Jakarta, Indonesia

$12^{\mathrm{c}}$ Global Geophysics Research Group, Faculty of Mining and Petroleum 13Engineering, Institut Teknologi Bandung, Jalan Ganesa No. 10, Bandung 40132, 14Indonesia $15^{\mathrm{d}}$ Research Center for Disaster Mitigation, Institut Teknologi Bandung, 16Jalan Ganesa No. 10, Bandung 40132, Indonesia $17^{\mathrm{e}}$ ISTerre, IRD R219, CNRS, Université de Savoie Mont Blanc, Le Bourget-du18Lac, France 19f Institut de Physique du Globe de Paris, Université Sorbonne-Paris-Cité, CNRS, 20France $21^{\mathrm{g}}$ Department of Earth Sciences - Bullard Labs, University of Cambridge, 22Cambridge CB30EZ, United Kingdom $23^{\mathrm{h}}$ Faculty of Earth Sciences and Technology, Institut Teknologi Bandung, 24Jalan Ganesa No. 10, Bandung 40132, Indonesia 
$26^{\mathrm{i}}$ Center for Volcanology and Geological Hazard Mitigation, Geological Agency, 27Jalan Diponegoro No. 57, Bandung, 40122, Indonesia

28

29*Corresponding author: sriwid@geoph.itb.ac.id

30

31A B S T R A C T

32Mt. Merapi, located in central Java, Indonesia, is one of the most active volcanoes 33in the world. It has been subjected to numerous studies using a variety of 34methods, including tomographic imaging, in an attempt to understand the 35structure and dynamics of its magmatic plumbing system. Results of previous 36seismic tomographic studies that include Mt. Merapi poorly constrain the location 37of its underlying magma source due to limited data coverage. In order to 38comprehensively understand the internal structure and magmatism of Mt. Merapi, 39a project called DOMERAPI was conducted, in which 53 broadband seismic 40stations were deployed around Mt. Merapi and its neighbourhood for 41approximately 18 months, from October 2013 to April 2015. In this study, we 42compare $\mathrm{Vp}, \mathrm{Vs}$, and $\mathrm{Vp} / \mathrm{Vs}$ tomograms constructed using data obtained from 43local (DOMERAPI) and regional seismic networks with those obtained without 44DOMERAPI data. We demonstrate that the data from the DOMERAPI seismic 45network are crucial for resolving key features beneath the volcano, such as high $46 \mathrm{Vp} / \mathrm{Vs}$ ratios beneath the Merapi summit at $\sim 5 \mathrm{~km}$ and $\sim 15 \mathrm{~km}$ depths, which we 47interpret as shallow and intermediate magma bodies, respectively. Furthermore, 48west-east vertical sections across Mt. Merapi, and a "dormant" (less active) 
49volcano, Mt. Merbabu, exhibit high $\mathrm{Vp} / \mathrm{Vs}$ and low $\mathrm{Vp} / \mathrm{Vs}$ ratios, respectively, 50directly beneath their summits. This observation likely reflects the presence (for 51Mt. Merapi) and absence (for Mt. Merbabu) of shallow magma bodies near the 52surface.

53

54Keywords:

55DOMERAPI

56Merapi

$57 \mathrm{Merbabu}$

58Tomography

59

601. Introduction

61 The origin of Mt. Merapi, located in the central part of Java in the eastern 62Sunda arc of Indonesia, can be traced back to the subduction of the Indo63Australian plate beneath the Eurasian plate (Widiyantoro et al., 2011; 64Widiyantoro and van der Hilst, 1996). This volcano is one of the most active 65stratovolcanoes in the world, with an eruption frequency of between two to six 66years. For example, eruptions occurred in 1984, 1986, 1992, and 1994 67(Ratdomopurbo and Poupinet, 2000). Very large eruptions tend to occur with a 68frequency of between 50 to 100 years (Lühr et al., 2013; Surono et al., 2012). 69Eruptions of the Merapi volcano are usually dominated by pyroclastic flows 70caused by the collapse of the lava dome (Hidayati et al., 2008). However, a large 
71eruption in 2010 exhibited a number of features that had not previously been 72observed in past eruptions. For instance, the initial eruption was explosive with a 73rating of $\sim 4$ (Komorowski et al., 2013; Surono et al., 2012) on the Volcanic 74Explosivity Index (VEI), reflecting the sizable volume of ejecta that was 75liberated. The frequency and size of eruptions that characterize Mt Merapi has 76attracted a range of researchers from different disciplines to study the ongoing 77activity at and below the summit of this unique volcano.

78 The results of the 2004 MERapi AMphibious EXperiment (MERAMEX) 79project were successful in explaining the relationship between the volcanic arc 80and the subduction zone in central Java. For instance, P- and S-wave velocity 81anomalies appear to depict the migration pathway of fluid or molten rocks from 82the partial melting zone at depth toward the surface beneath the volcanic arc 83(Haberland et al., 2014; Koulakov et al., 2007; Wagner et al., 2007). The results 84of these studies have been updated using additional data from the Indonesian 85Meteorological, Climatological and Geophysical Agency (BMKG) catalogue 86(Rohadi et al., 2013). However, even this more recent investigation has not been 87able to image the magma reservoirs beneath Merapi in any detail due to a lack of 88seismic data coverage. More localized studies using volcano-tectonic earthquake 89data show that volcanic events occur down to depths of $\sim 5 \mathrm{~km}$ below the summit 90of Mt. Merapi (Budi-Santoso et al., 2013; Hidayati et al., 2008; Ratdomopurbo 91and Poupinet, 2000), which means that seismic velocity structure at depths $>\sim 5$ $92 \mathrm{~km}$ cannot be determined using these shallow events.

93 The DOMERAPI project, which involved the deployment of 53 broadband 94seismic stations around Mt. Merapi between 2013 and 2015, was carried out in 
95part to image magma bodies beneath the volcano in unprecedented detail. 96Widiyantoro et al. (2018) used relocated events from the DOMERAPI and 97BMKG networks (Ramdhan et al., 2017) to investigate the magma plumbing 98system beneath Merapi. In this study, we have carried out seismic tomography 99using the DOMERAPI data combined with data recorded by other seismic 100networks, including the BMKG network, the MERAMEX network and the 101Indonesian Institute for Research and Development of Geological Disaster 102Technology (BPPTKG) network. Our results clearly demonstrate that the 103inclusion of the DOMERAPI data significantly improves the imaging of possible 104magma bodies.

105

1062. Data and methodology

1072.1. Data

108 In this study, we have combined data from the DOMERAPI, BMKG, 109MERAMEX, and BPPTKG seismic networks to maximize the data coverage 110around the Merapi area. We used the BMKG and BPPTKG data from the same 111recording period as the DOMERAPI project period, i.e. from October 2013 to 112April 2015. In the case of MERAMEX, data were collected from May to 113September 2004. Fig. 1 shows the distribution of the four seismic networks used 114in this study.

115 In total, 942 events were extracted from the four seismic networks; 464 116earthquakes were recorded by the DOMERAPI and BMKG seismographic 117stations in the same period, 260 of which were also recorded by the BPPTKG 118stations. The total number of earthquakes recorded by the MERAMEX stations 
119was 282. The remaining 196 events were taken from the BMKG catalog beyond 120the DOMERAPI recording period in order to minimize the azimuthal gap in the 121hypocenter determination process. All earthquakes were relocated prior to 122tomographic inversion. The total number of earthquakes that were successfully 123relocated is 794, with the remaining 148 discarded due to poor data fit. A detailed 124analysis of event locations from the DOMERAPI and BMKG networks is 125available in Ramdhan et al. (2017).

126 The earthquake data used for tomography are restricted to the longitude and 127latitude ranges $108^{0}-112^{0} \mathrm{E}$ and $6^{0}-11^{\circ} \mathrm{S}$, respectively (Fig. 2). For this region, we 128end up with a total of 767 relocated events that were recorded by 254 129seismographic stations (53 from DOMERAPI, 17 BMKG, 167 MERAMEX, and 13017 BPPTKG seismometers). Each earthquake used for tomographic inversion is 131recorded by at least six seismographic stations. Fig. 2 shows the distribution of 132epicenters, seismometers, and the inversion grid (which is used to define 133variations in velocity structure) employed in this study (see Figs. S1 and S2 in the 134Supplementary Materials for the distribution of hypocenters and ray paths). 135

1362.2. Methodology

137 For this study, hypocenters were located using the Geiger method (Geiger, 1381912), as implemented in the Hypoellipse program (Lahr, 1999). This technique 139was successfully applied to map earthquake distribution along several faults in 140western Java by Supendi et al. (2018). For a reference velocity model (see Table 1411), we adopted the 1-D P-wave velocity model of Koulakov et al. (2007) and used 142a Vp/Vs ratio of 1.73 taken from Ramdhan et al. (2017). The hypocenter 
143relocation technique employed in this study is the double-difference method 144(Waldhauser, 2001; Waldhauser and Ellsworth, 2000). Previously, this method 145was also successfully applied to relocate earthquakes from the BMKG catalog in 146several other regions in Indonesia (Cahyaningrum et al., 2015; Ramdhan and 147Nugraha, 2013; Sabtaji and Nugraha, 2015; Utama et al., 2015). To conduct the 148travel-time tomography, we used the SIMULPS12 codes (Eberhart-Phillips, 1993; 149Evans et al., 1994), which have been widely used to image subsurface structure in 150many parts of the world. For instance, they were used in the study of Nugraha and 151Mori, 2006, who clearly detected the subducted slab beneath the Shikoku and 152Bungo channels in Japan. Furthermore, these codes were also used by Nugraha et 153al., 2015, who managed to clearly detect a subducting slab beneath the Bali, 154Lombok, and Sumbawa Islands in the eastern Sunda arc. SIMULPS12 was also 155successfully applied to delineate structure beneath several Indonesian volcanoes, 156including Mt. Lokon in Sulawesi by Firmansyah et al. (2015) and Mt. Guntur in 157western Java by Nugraha et al. (2013). Inversions were performed for Vp and $158 \mathrm{Vp} / \mathrm{Vs}$ ratio simultaneously. Determination of $\mathrm{Vp} / \mathrm{Vs}$ ratio via direct inversion of 159S-P arrival time differences is more reliable compared to separately inverting for $160 \mathrm{Vs}$ and then dividing $\mathrm{Vp}$ by $\mathrm{Vs}$, because in general the quality of $\mathrm{S}$ data is not as 161good as the quality of P data (Eberhart-Phillips, 1993). Moreover, Vp and Vp/Vs 162tomograms are very useful for interpreting not only structural features, but also 163the physical properties of rocks. The computation of the 3-D seismic velocity 164structure beneath Mt. Merapi and its surrounding areas used a relatively small grid 165spacing of $10 \mathrm{~km}$ in the horizontal direction and $5 \mathrm{~km}$ in the vertical direction 166down to $35 \mathrm{~km}$ depth. For greater depths, where the data coverage is more sparse, 
167we used a coarser grid spacing (Table 2). For selecting optimal damping values 168we constructed trade-off curves showing model variance versus data variance, as 169displayed in Fig. 3.

170

\section{Tomographic imaging results}

172 In this section, we present our final $\mathrm{Vp}, \mathrm{Vs}$, and $\mathrm{Vp} / \mathrm{Vs}$ tomograms along 173with resolution test results. We also demonstrate that the inclusion of the 174DOMERAPI data set produces significant improvements in the recovery of 175detailed structure beneath Mt. Merapi.

176

\subsection{Resolution tests}

178 Resolution tests were conducted to understand which structural features can 179be resolved by the data. In this study, we employed conventional checkerboard 180tests. Positive and negative perturbations of $\pm 10 \%$ relative to the 1 -D reference 181velocity model were used as inputs in the tests. If the inversion results show that 182one grid/block has the same anomaly (positive or negative) as the input model, 183even with a reduction in amplitude due to the implementation of damping, we 184consider that block to be resolved by the data. We can then interpret those parts of 185the model that are considered to be resolved by this approach, while keeping in 186mind the limitations of the checkerboard test in assessing the resolution of 187tomograms (Lévěque et al., 1993, Rawlinson and Spakman, 2016). Here, we 188emphasize the improved resolution due to the incorporation of the DOMERAPI 189data. 


\section{2. $V p$, $V s$, and $V p / V s$ tomograms}

192 To recover the seismic velocity structure beneath the Merapi volcano and its 193surroundings, we used a total of $29,937(20,185 \mathrm{P}$ and $9,752 \mathrm{~S})$ ray paths from 194local events. Vp anomalies are stated in percent (perturbations) relative to the 1-D 195initial velocity model used in the inversion, whereas $\mathrm{Vp} / \mathrm{Vs}$ ratios are in absolute 196values. The Vp/Vs ratio is directly proportional to Poisson's ratio, which is 197sensitive to temperature and the presence of fluid. The presence of magma or 198molten material is typically characterised by a high $\mathrm{Vp} / \mathrm{Vs}$ ratio (see e.g. 199Nakajima et al., 2001). Regions of the model that will be discussed are only those 200with good resolution based on the checkerboard test results.

201 The pattern of anomalies that characterise the $\mathrm{Vp}$ and $\mathrm{Vp} / \mathrm{Vs}$ models may 202well be different because the Vp/Vs model strongly depends on Vs, which is a 203more sensitive indicator of fluids compared to Vp. Therefore, we present not only $204 \mathrm{Vp}$ and $\mathrm{Vp} / \mathrm{Vs}$ models, but also the Vs model. In the following, west-east vertical 205sections across Mt. Merbabu and Mt. Merapi are presented in order to directly 206compare the internal structures of these two volcanoes. In Fig. 4 (a-c), we display 207A-A' vertical sections through $\mathrm{Vp}, \mathrm{Vs}$, and $\mathrm{Vp} / \mathrm{Vs}$ models from joint inversions 208using the DOMERAPI, MERAMEX, BMKG, and BPPTKG data. We also show 209similar cross sections, but derived by excluding the DOMERAPI data (Fig. 4 d-f). 210The differences between these sections are plotted with a more restricted 211perturbation scale to highlight the improvement due to the inclusion of 212DOMERAPI data (Fig. 4 g-i). The results of checkerboard tests for the associated 213cross sections are presented in Fig. 5. Here, we also demonstrate the improved 214checkerboard recovery owing to the inclusion of the DOMERAPI data, which are 
215quite pronounced for the region beneath Merapi. A similar presentation of 216tomograms is given in Fig. 6 for west-east (B-B') vertical sections across Merapi 217from the Vp, Vs, and Vp/Vs models. The corresponding checkerboard resolution 218test results are displayed in Fig. 7. Map views are also presented in Figs. 8 and 9, 219i.e. horizontal slices at $5 \mathrm{~km}$ depth through the $\mathrm{Vp}, \mathrm{Vs}$, and $\mathrm{Vp} / \mathrm{Vs}$ models along 220with the corresponding checkerboard resolution test results. Horizontal slices 221across a range of depths are also presented in Figs. S3 and S4. The results of 222resolution tests in which Gaussian noise is added to the synthetic data are shown 223in Figs. S5 and S6. In what follows, we discuss and interpret these tomograms, 224with a focus on the possible existence of magma bodies beneath the Merapi 225volcano.

226

\section{Discussion}

228 In this section, we concentrate our discussion on the internal structures of Mt. 229Merbabu and Mt. Merapi, which represent "dormant" and active volcanoes, 230respectively. We also discuss the significant improvement in the resulting 231tomographic images owing to the incorporation of the DOMERAPI data.

232

2334.1. Mt. Merbabu vs Mt. Merapi

234 The west-east (A-A') vertical sections through Vp, Vs, and Vp/Vs models 235shown in Fig. 4 depict the internal structure of Mt. Merbabu. A low Vp/Vs ratio is 236observed from the summit to depths of $\sim 20$ to $\sim 25 \mathrm{~km}$ below mean sea level 237(MSL), a region which the checkerboard test results suggest is well resolved (Fig. 2385). The low $\mathrm{Vp} / \mathrm{Vs}$ ratio directly beneath the summit down to a depth of $\sim 5 \mathrm{~km}$ is 
239associated with high Vp and higher Vs. On the other hand, the low Vp/Vs ratio at 240greater depths is due to very low Vp and low Vs (cf. Widiyantoro et al., 2018). 241These anomalies are unlikely to be related to the presence of fluids or melts, 242which is consistent with the fact that Mt. Merbabu is not currently active, with the 243last known activity being a moderate eruption that occurred in 1797 (van 244Hinloopen Labberton, 1921). This last eruption was rated 2 on the VEI (cf. VEI 245 4 for the Merapi eruption of 2010 ; Komorowski et al., 2013; Surono et al., 2462012).

247 Fig. 6 also displays west-east vertical sections through the Vp, Vs, and Vp/Vs 248models, but across Mt. Merapi (B-B'). In contrast to Fig. 4, we evidently have a 249high $\mathrm{Vp} / \mathrm{Vs}$ ratio beneath the summit down to a depth of $\sim 5 \mathrm{~km}$ below MSL, 250which is due to low Vp and very low Vs. In addition, we also observe a very high $251 \mathrm{Vp} / \mathrm{Vs}$ ratio at a depth of $\sim 15 \mathrm{~km}$ that is associated with high $\mathrm{Vp}$ and low $\mathrm{Vs}$ 252anomalies. The results of the checkerboard tests displayed in Fig. 7 indicate that 253in general, structures beneath Merapi are well resolved down to a depth of $\sim 25$ $254 \mathrm{~km}$, particularly when the DOMERAPI data are included. We interpret the high $255 \mathrm{Vp} / \mathrm{Vs}$ ratio as being related to the presence of fluids or melts, while the deeper 256high $\mathrm{Vp} / \mathrm{Vs}$ ratio is interpreted as an intermediate magma reservoir, as suggested 257by Costa et al., 2013 based on petrological studies.

258 The internal structures of Mt. Merbabu and Mt. Merapi are much more 259clearly imaged when the DOMERAPI data are included, as illustrated by the 260difference between models derived with and without this data set. The most 261intriguing features are the shallow and intermediate high $\mathrm{Vp} / \mathrm{Vs}$ ratios beneath 262Merapi that are constrained by the DOMERAPI data (Fig. 6 i). These structural 
263features are well resolved (see Fig. 7 f). We interpret these two anomalies as 264shallow and intermediate magma bodies that underlie Merapi. Costa et al. (2013) 265also suggest the existence of an even deeper reservoir, at approximately the depth 266of the Moho. However, the presence or absence of such a deep reservoir cannot be 267determined by the data set used in this study, which do not constrain the 268lowermost crust or uppermost mantle

269 The $5 \mathrm{~km}$ depth slices through the Vp, Vs, and Vp/Vs tomograms depict two 270distinct features: (i) low Vp and Vs anomalies in the neighbourhood of the Merapi 271and Merbabu complex, and (ii) a high Vp/Vs ratio below Merapi, but not beneath 272Merbabu. The first observation, in particular the strong low velocity zone east of 273Merapi and Merbabu, is in good agreement with the important finding by 274Koulakov et al., 2007 of a very low Vp and Vs anomaly beneath central Java, 275called the Merapi-Lawu Anomaly. The second observation of the high and low 276Vp/Vs ratios beneath Merapi and Merbabu, respectively, is likely related to 277Merapi being an active volcano and Merbabu being "dormant".

278

2794.2. Improved resolution due to the inclusion of DOMERAPI data

280 In Figs. 4-9, we demonstrate the important contribution of the DOMERAPI 281seismic network in improving the resolution of $\mathrm{Vp}$ and $\mathrm{Vp} / \mathrm{Vs}$ models, especially 282underneath Mt. Merapi. Compared with a number of previous studies which used 283travel-time tomography (e.g. Wagner et al. 2007; Koulakov et al. 2007; Rohadi et 284al. 2013; Haberland et al. 2014), the inclusion of the DOMERAPI data illuminates 285the magma system below the Merapi volcano in much more detail. From the 286checkerboard test results, it is clearly seen that the seismic resolution beneath 
287Merapi and its surroundings is greatly enhanced, especially in the crust $(<25 \mathrm{~km})$; 288see Figs. 5 and 7. For the sake of completeness, we also include slices from 289deeper regions of the models and their associated resolution tests in Figs. S7 and $290 \mathrm{~S} 8$.

291

\section{Concluding Remarks}

293 The additional data set from the DOMERAPI seismic network has 294significantly increased seismic ray coverage and hence the resolution of structural 295features beneath the Merapi volcano, especially for depths above $25 \mathrm{~km}$. The 296incorporation of this new data set has permitted us to observe several important 297structural features in unprecedented detail, therefore allowing us to produce a 298more reliable interpretation. In particular, we detected the presence of shallow and 299intermediate magma bodies as indicated by high $\mathrm{Vp} / \mathrm{Vs}$ ratios beneath Mt. 300Merapi. In contrast to Mt. Merapi, however, the internal structure of Mt. Merbabu 301is dominated by high velocity anomalies and a low Vp/Vs ratio, confirming that 302Merbabu is much less active than Merapi.

303 In future studies, we will conduct Qp and Qs tomographic investigations 304using the same data set; this will complement our current results because Q is 305more sensitive to temperature and the presence of fluids compared to seismic 306velocities. Moreover, seismic velocity and attenuation (1/Q) anomalies can be 307 more reliably interpreted in terms of temperature variations by making use of 308 constraints from laboratory studies of rock properties at different temperatures and 309pressures. 


\section{Acknowledgements}

312 We are grateful to the French National Research Agency and Institut de 313recherche pour le développemen for funding the DOMERAPI project. We would 314also like to express our gratitude to PVMBG as the main partner of the 315DOMERAPI project in Indonesia, and BMKG for providing us with the 316earthquake data catalog used in this study. Thanks go to GFZ for granting access 317to the MERAMEX data, and Lembaga Pengelola Dana Pendidikan (LPDP), the 318Republic of Indonesia, for granting a doctoral scholarship to MR. This study was 319also supported in part by Direktorat Perguruan Tinggi (DIKTI), the Republic of 320Indonesia, through a WCU research grant 2016/2017, and a 2018 research grant 321 from Institut Teknologi Bandung (ITB) awarded to SW. We are grateful for the 322constructive and helpful comments from the two anonymous reviewers. All 323images in this paper were plotted using the GMT program (Wessel and Smith, 3241998).

325

\section{References}

327Budi-Santoso, A., Lesage, P., Dwiyono, S., Sumarti, S., Subandriyo, Surono, 328 Jousset, P., Metaxian, J.-P., 2013. Analysis of the seismic activity 329 associated with the 2010 eruption of Merapi Volcano, Java. J. Volcanol. $330 \quad$ Geotherm. Res. 261, 153-170.

$331 \quad$ https://doi.org/10.1016/j.jvolgeores.2013.03.024.

332Cahyaningrum, A.P., Nugraha, A.D., Nanang, T.P., 2015. Earthquake hypocenter 333 relocation using double difference method in East Java and surrounding 334 areas. AIP Conf. Proc. 1658, 030021. https://doi.org/10.1063/1.4915029. 
335Costa, F., Andreastuti, S., Bouvet de Maisonneuve, C., Pallister, J.S., 2013.

336 Petrological insights into the storage conditions, and magmatic processes

337 that yielded the centennial 2010 Merapi explosive eruption. J. Volcanol.

$338 \quad$ Geotherm. Res. 261, 209-235.

339 https://doi.org/10.1016/j.jvolgeores.2012.12.025.

340Eberhart-Phillips, D., 1986. Three-dimensional velocity structure in northern

341 California Coast Ranges from inversion of local earthquake arrival times.

342 Bull. Seismol. Soc. Am. 76, 1025-1052.

343Eberhart-Phillips, D., 1993. Local earthquake tomography: earthquake source

344 regions. Seismic Tomography: Theory and Practice 613-643.

345Evans, J.R., Eberhart-Phillips, D., Thurber, C., 1994. User's manual for

346 SIMULPS12 for imaging $\mathrm{Vp}$ and $\mathrm{Vp} / \mathrm{Vs}$; a derivative of the " Thurber"

347 tomographic inversion SIMUL3 for local earthquakes and explosions. U.

348 S. Geol. Surv. Open File Rep. 94-431.

349Firmansyah, R., Nugraha, A.D., Kristianto, 2015. The preliminary results: Internal 350 seismic velocity structure imaging beneath Mount Lokon. AIP Conf. Proc. $351 \quad 1658,050012$. https://doi.org/10.1063/1.4915051.

352Geiger, L., 1912. Probability method for the determination of earthquake

353 epicenters from the arrival time only. Bull. St. Louis Univ. 8, 56-71.

354Haberland, C., Bohm, M., Asch, G., 2014. Accretionary nature of the crust of

355 Central and East Java (Indonesia) revealed by local earthquake travel-time

356 tomography. J. Asian Earth Sci. 96, 287-295.

357 https://doi.org/10.1016/j.jseaes.2014.09.019. 
358Hidayati, S., Ishihara, K., Iguchi, M.M., Ratdomopurbo, A., 2008. Focal

359 mechanism of volcano-tectonic earthquakes at Merapi volcano, Indonesia.

360 Indones. J. Phys.19(3), 75-82.

361Komorowski, J.-C., Jenkins, S., Baxter, P.J., Picquout, A., Lavigne, F.,

362 Charbonnier, S., Gertisser, R., Preece, K., Cholik, N., Budi-Santoso, A.,

363 Surono, 2013. Paroxysmal dome explosion during the Merapi 2010

364 eruption: Processes and facies relationships of associated high-energy

365 pyroclastic density currents. J. Volcanol. Geotherm. Res. 261, 260-294.

366 https://doi.org/10.1016/j.jvolgeores.2013.01.007.

367Koulakov, I., Bohm, M., Asch, G., Lühr, B.-G., Manzanares, A., Brotopuspito,

368 K.S., Fauzi, P., Purbawinata, M.A., Puspito, N.T., Ratdomopurbo, A.,

369 Kopp, H., Rabbel, W., Shevkunova, E., 2007. P and S velocity structure of

370 the crust and the upper mantle beneath central Java from local tomography

371 inversion. J. Geophys. Res. 112, B08310.

372 https://doi.org/10.1029/2006JB004712.

373Lahr, J., 1999. Revised 2012, HYPOELLIPSE: A computer program for

374 determining local earthquake hypocentral parameters, magnitude, and

375 first-motion pattern. U. S. Geol. Surv. Open File Rep. 99-23.

$376 \quad$ https://doi.org/10.3133/ofr9923.

377Lévěque, J.-J., Rivera, L., Wittlinger, G., 1993. On the use of the checker-board

378 test to assess the resolution of tomographic inversions. Geophys. J. Int.

$379 \quad 115,313-318$. https://doi.org/10.1111/j.1365-246X.1993.tb05605.x.

380Lühr, B.-G., Koulakov, I., Rabbel, W., Zschau, J., Ratdomopurbo, A.,

381 Brotopuspito, K.S., Fauzi, P., Sahara, D.P., 2013. Fluid ascent and magma 
storage beneath Gunung Merapi revealed by multi-scale seismic imaging.

383 J. Volcanol. Geotherm. Res. 261, 7-19.

384 https://doi.org/10.1016/j.jvolgeores.2013.03.015

385Nakajima, J., Matsuzawa, T., Hasegawa, A., Zhao, D., 2001. Three-dimensional 386 structure of $\mathrm{Vp}$, Vs, and Vp/Vs beneath northeastern Japan: Implications

387 for arc magmatism and fluids. J. Geophys. Res. 106, 21843-21858. DOI:

388 10.1029/2000JB000008

389Nugraha, A.D., Kusnandar, R., Puspito, N.T., Sakti, A.P., Yudistira, T., 2015.

390 Preliminary results of local earthquake tomography around Bali, Lombok, 391 and Sumbawa regions. AIP Conf. Proc. 1658, 030019.

392 https://doi.org/10.1063/1.4915027.

393Nugraha, A.D., Mori, J., 2006. Three-dimensional velocity structure in the Bungo 394 Channel and Shikoku area, Japan, and its relationship to low-frequency 395 earthquakes. Geophys. Res. Lett. 33, L24307. 396 https://doi.org/10.1029/2006GL028479.

397Nugraha, A.D., Widiyantoro, S., Gunawan, A., Suantika, G., 2013. Seismic 398 Velocity Structures beneath the Guntur Volcano Complex, West Java, 399 Derived from Simultaneous Tomographic Inversion and Hypocenter 400 Relocation. J. Math. Fund. Sci. 45(1), 17-28.

401Ramdhan, M., Nugraha, A.D., 2013. Study of seismicity around Toba area based 402 on relocation hypocenter result from BMKG catalogue. AIP Conf. Proc. $403 \quad 1554,242$. https://doi.org/10.1063/1.4820330.

404Ramdhan, M., Widiyantoro, S., Nugraha, A.D., Métaxian, J.-P., Saepuloh, A., 405 Kristyawan, S., Sembiring, A.S., Santoso, A.B., Laurin, A., Fahmi, A.A., 
407 a preliminary result from DOMERAPI project. Earthq. Sci.

$408 \quad$ https://doi.org/10.1007/s11589-017-0178-3.

409Ratdomopurbo, A., Poupinet, G., 2000. An overview of the seismicity of Merapi

410 volcano (Java, Indonesia), 1983-1994. J. Volcanol. Geotherm. Res. 100,

411 193-214. https://doi.org/10.1016/S0377-0273(00)00137-2.

412Rawlinson, N., Spakman, W., 2016. On the use of sensitivity tests in seismic

413 tomography, Geophys. J. Int. 205(2), 1221-1243. DOI:

$414 \quad 10.1093 /$ gji $/$ ggw084.

415Rohadi, S., Widiyantoro, S., Nugraha, A.D., Masturyono, 2013. Tomographic

416 imaging of P-and S-wave velocity structure beneath central Java,

417 Indonesia: Joint inversion of the MERAMEX and MCGA earthquake data.

418 Int. J. Tomogr. Stat. 24(3), 1-16.

419Sabtaji, A., Nugraha, A.D., 2015. 1-D seismic velocity model and hypocenter 420 relocation using double difference method around West Papua region. AIP

421 Conf. Proc. 1658, 030005. https://aip.scitation.org/doi/10.1063/1.4915013.

422Supendi, P., Nugraha, A.D., Puspito, N.T., Widiyantoro, S., Daryono, D., 2018.

423 Identification of active faults in West Java, Indonesia, based on earthquake

424 hypocenter determination, relocation, and focal mechanism analysis.

$425 \quad$ Geosci. Lett. 5, 31. https://doi.org/10.1186/s40562-018-0130-y.

426Surono, Jousset, P., Pallister, J., Boichu, M., Buongiorno, M.F., Budisantoso, A., 427 Costa, F., Andreastuti, S., Prata, F., Schneider, D., Clarisse, L., Humaida,

428 H., Sumarti, S., Bignami, C., Griswold, J., Carn, S., Oppenheimer, C.,

429 Lavigne, F., 2012. The 2010 explosive eruption of Java's Merapi volcano 
432Utama, M.R.J., Nugraha, A.D., Puspito, N.T., others, 2015. Seismicity studies at 433 Moluccas area based on the result of hypocenter relocation using hypoDD. 434 AIP Conf. Proc. 1658, 030022. https://doi.org/10.1063/1.4915030. 435van Hinloopen Labberton, D., 1921. Oud-Javaansche gegevens omtrent de $436 \quad$ vulkanologie van Java. Djdwd 1:185-201.

437Wagner, D., Koulakov, I., Rabbel, W., Lühr, B.-G., Wittwer, A., Kopp, H., Bohm, 438 M., Asch, G., MERAMEX Scientists, 2007. Joint inversion of active and 439 passive seismic data in Central Java. Geophys. J. Int. 170, 923-932. $440 \quad$ https://doi.org/10.1111/j.1365-246X.2007.03435.x. 441Waldhauser, F., 2001. hypoDD-A Program to Compute Double-Difference 442 Hypocenter Locations (USGS Numbered Series No. 2001-113), Open-File $443 \quad$ Report. https://doi.org/10.3133/ofr01113.

444Waldhauser, F., Ellsworth, W.L., 2000. A double-difference earthquake location 445 algorithm: Method and application to the northern Hayward fault, 446 California. Bull. Seismol. Soc. Am. 90, 1353-1368. $447 \quad$ https://doi.org/10.1785/0120000006.

448Wessel, P., Smith, W.H.F., 1998. New, improved version of Generic Mapping 449 Tools Released. EOS Trans., AGU 79, 579, doi: 10.1029/98EO00426. 450Widiyantoro, S., Pesicek, J., Thurber, C., 2011. Subducting slab structure below 451 the eastern Sunda arc inferred from non-linear seismic tomographic 452 imaging. Geol. Soc. London Spec. Pub. 355, 139-155.

$453 \quad$ https://doi.org/10.1144/SP355.7. 
454Widiyantoro, S., Ramdhan, M., Métaxian, J.-P., Cummins, P.R., Martel, C., 455 Erdmann, S., Nugraha, A.D., Budi-Santoso, A., Laurin, A., Fahmi, A.A., 456 2018. Seismic imaging and petrology explain highly explosive eruptions 457 of Merapi Volcano, Indonesia. Sci. Rep. 8, 13656.

$458 \quad$ https://doi.org/10.1038/s41598-018-31293-w.

459Widiyantoro, S., van der Hilst, R., 1996. Structure and evolution of lithospheric 460 slab beneath the Sunda arc, Indonesia. Science 271, 1566. doi:

$461 \quad 10.1126 /$ science.271.5255.1566.

462

463

464

465

466

467Table 1

468Reference 1-D P- and S-wave velocity models. The Vp model is taken from 469Koulakov et al. (2007).

470

\begin{tabular}{|c|c|c|}
\hline Depth $(\mathrm{km})$ & $\mathrm{Vp}(\mathrm{km} / \mathrm{s})$ & $\mathrm{Vs}(\mathrm{km} / \mathrm{s})$ \\
\hline-3 & 4.30 & 2.49 \\
\hline 3 & 4.90 & 2.83 \\
\hline 8 & 5.70 & 3.29 \\
\hline 16 & 6.90 & 3.99 \\
\hline 24 & 7.10 & 4.10 \\
\hline 77 & 7.80 & 4.51 \\
\hline 120 & 8.05 & 4.65 \\
\hline 165 & 8.17 & 4.72 \\
\hline
\end{tabular}




\begin{tabular}{|l|l|l|}
\hline 210 & 8.30 & 4.80 \\
\hline
\end{tabular}

472

473

474

475

476

477

478Table 2

479Three-dimensional grid spacing used in the tomographic inversions. The center of 480the model is at $110.45^{\circ} \mathrm{E}$ and $7.54^{\circ} \mathrm{S}$.

481

\begin{tabular}{|c|c|}
\hline Grid direction & Grid distances from the center of the model $(\mathrm{km})$ \\
\hline $\mathrm{x}$ & $-500-350-160-120-80-50-30-20-10010203050$ \\
& 80120200500 \\
\hline $\mathrm{y}$ & $-600-450-80-50-30-20-1001020305080250400$ \\
\hline $\mathrm{z}$ & -200051015202530355080110150200590700 \\
\hline
\end{tabular}

483

484

485

486

487 


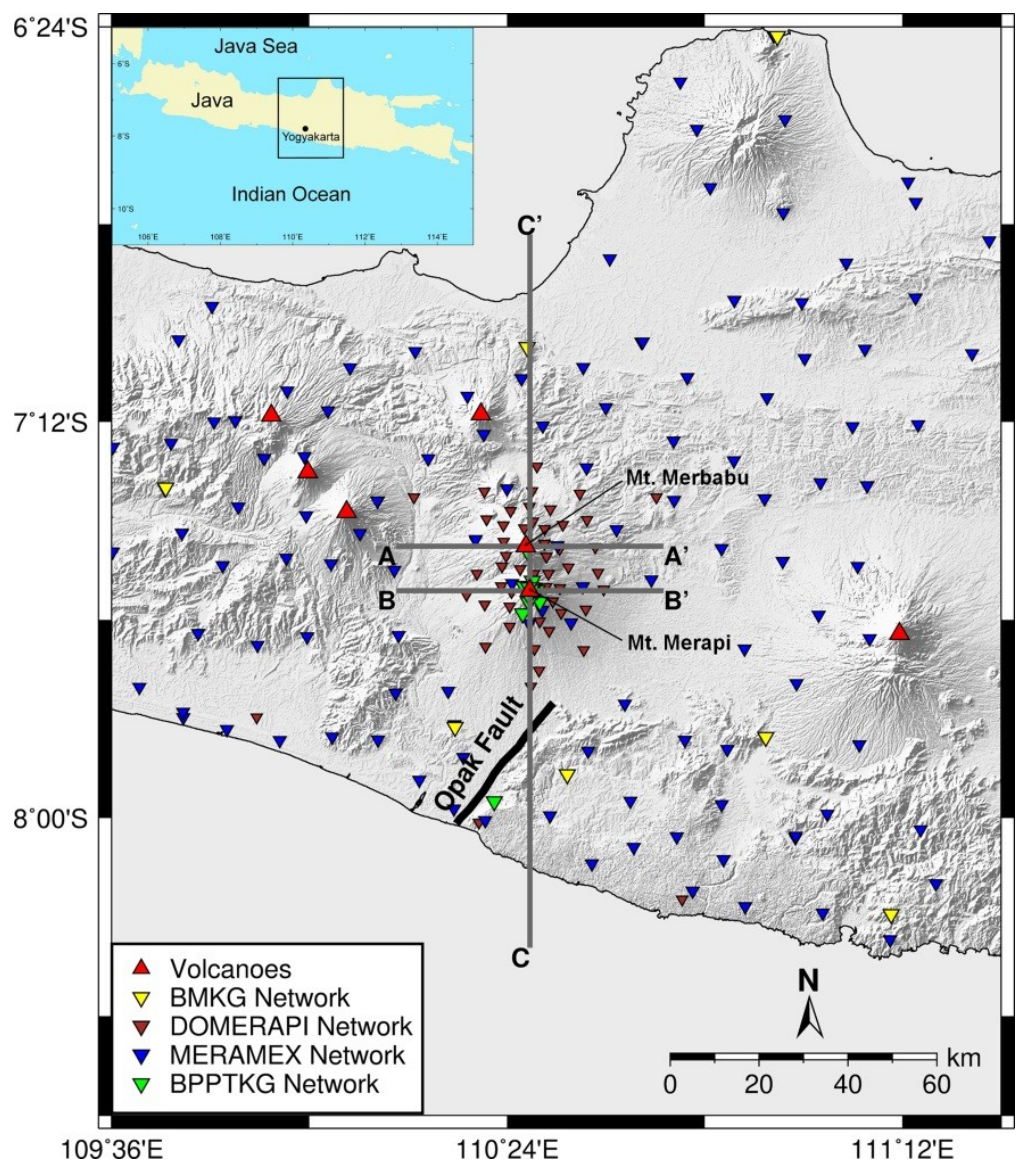

489Fig. 1. Map of the study region and the distribution of seismographic stations of 490the DOMERAPI, MERAMEX, BPPTKG and BMKG networks. Red triangles to 491the north of the Opak fault depict the locations of the Merapi and Merbabu 492volcanoes. See the legend in the inset for the definition of symbols used on the 493map. Lines A-A' and B-B' depict the locations of vertical sections shown in Figs. 4944 - 7, and Line C-C' depicts the location of deep vertical sections shown in Figs. 495S7 and S8. 


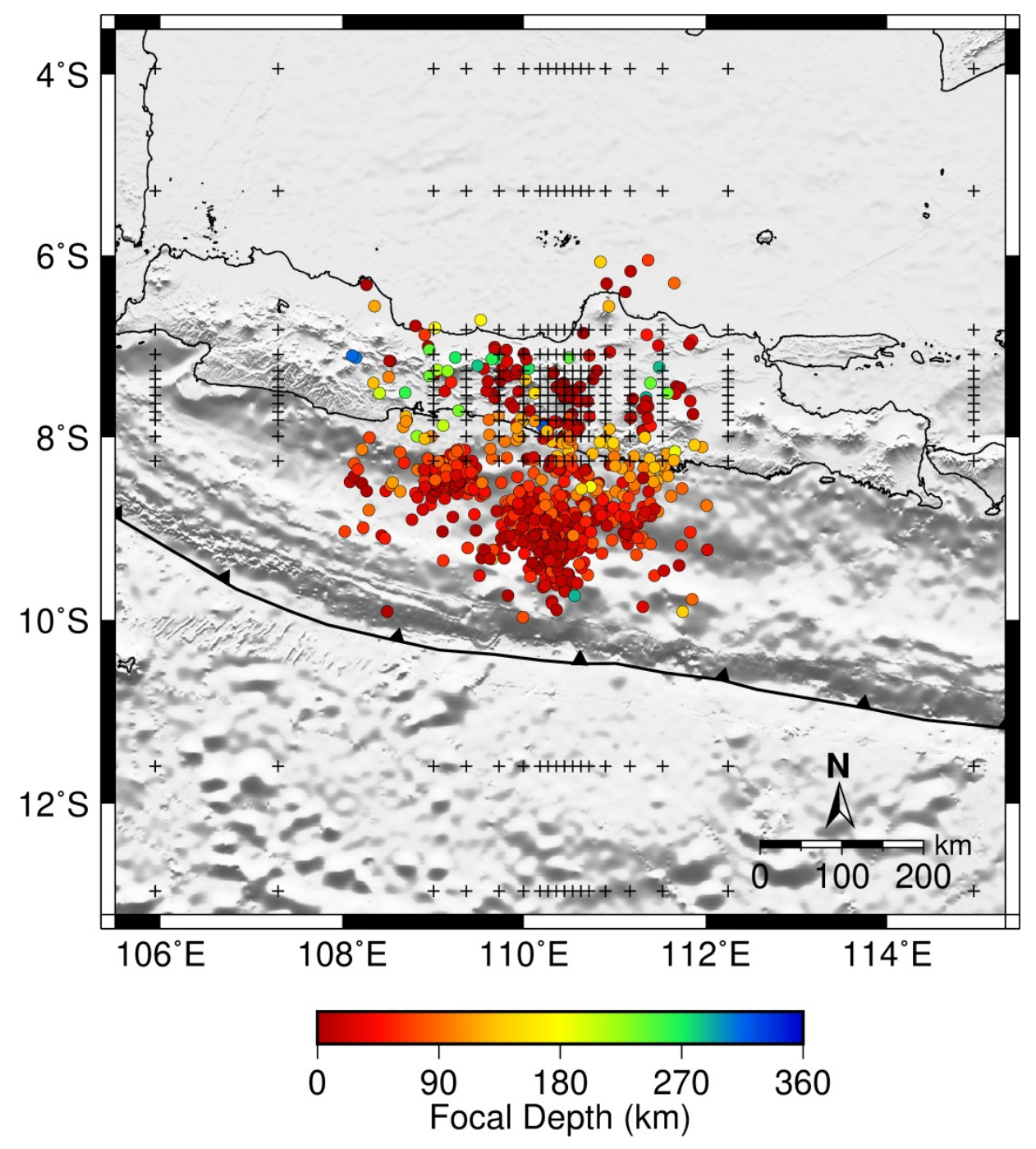

498Fig. 2. Configuration of grids used for seismic tomographic imaging and the 499distribution of epicenters produced by SIMULPS12.

500 

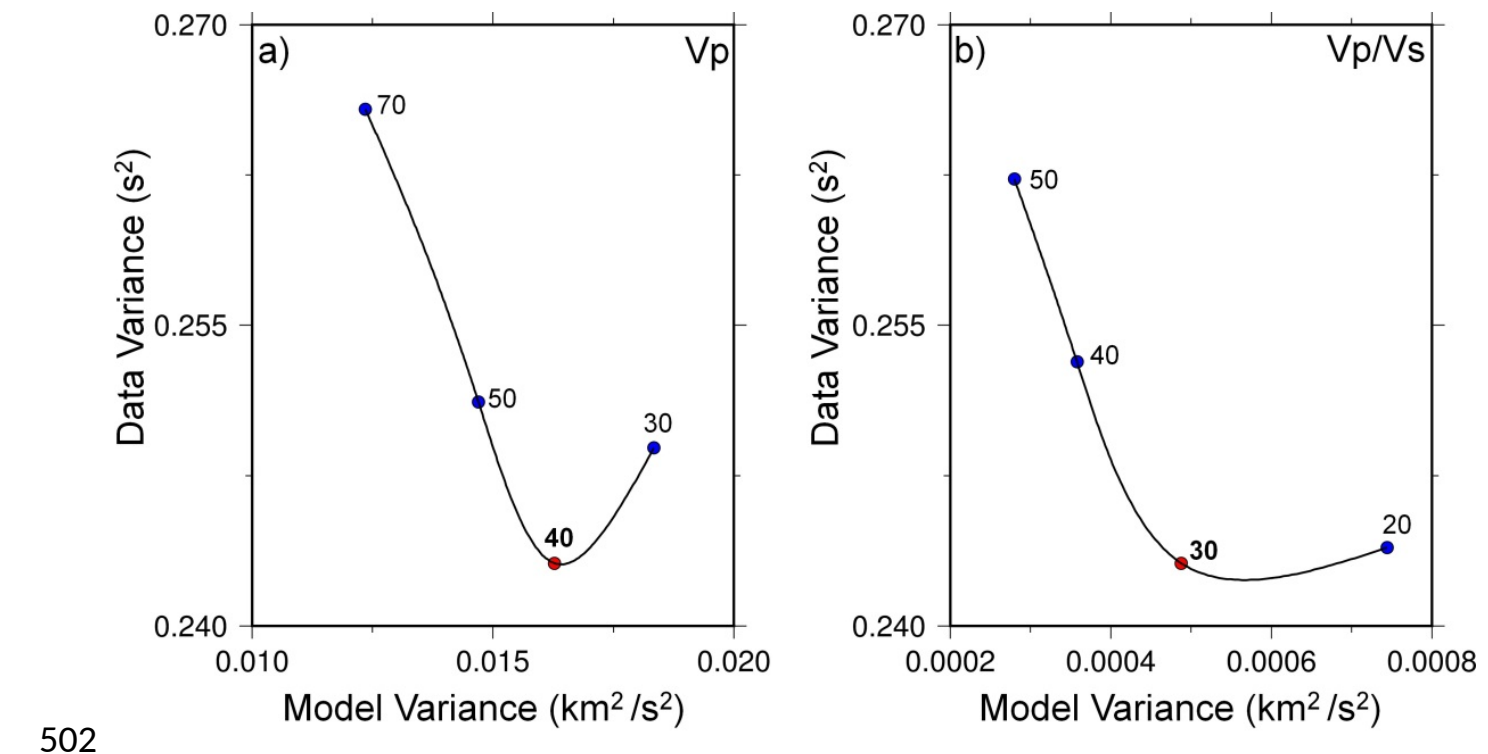

503Fig. 3. Trade-off curves showing model variance versus data variance, which is 504used for selecting optimal damping values. a) Damping values of 40 for $\mathrm{Vp}$, and 505b) 30 for $\mathrm{Vp} / \mathrm{Vs}$ (red dots), with a station damping value of 10, are selected for the 506inversions. The model and data variance are computed after one iteration for the 507indicated damping values. Note that when the damping values are too small 508(rightmost points), the velocity tends to oscillate from one grid point to the next, 509and strong velocity anomalies are introduced without significant reductions in 510data variance (Eberhart-Phillips, 1986; see also Widiyantoro et al., 2018). 

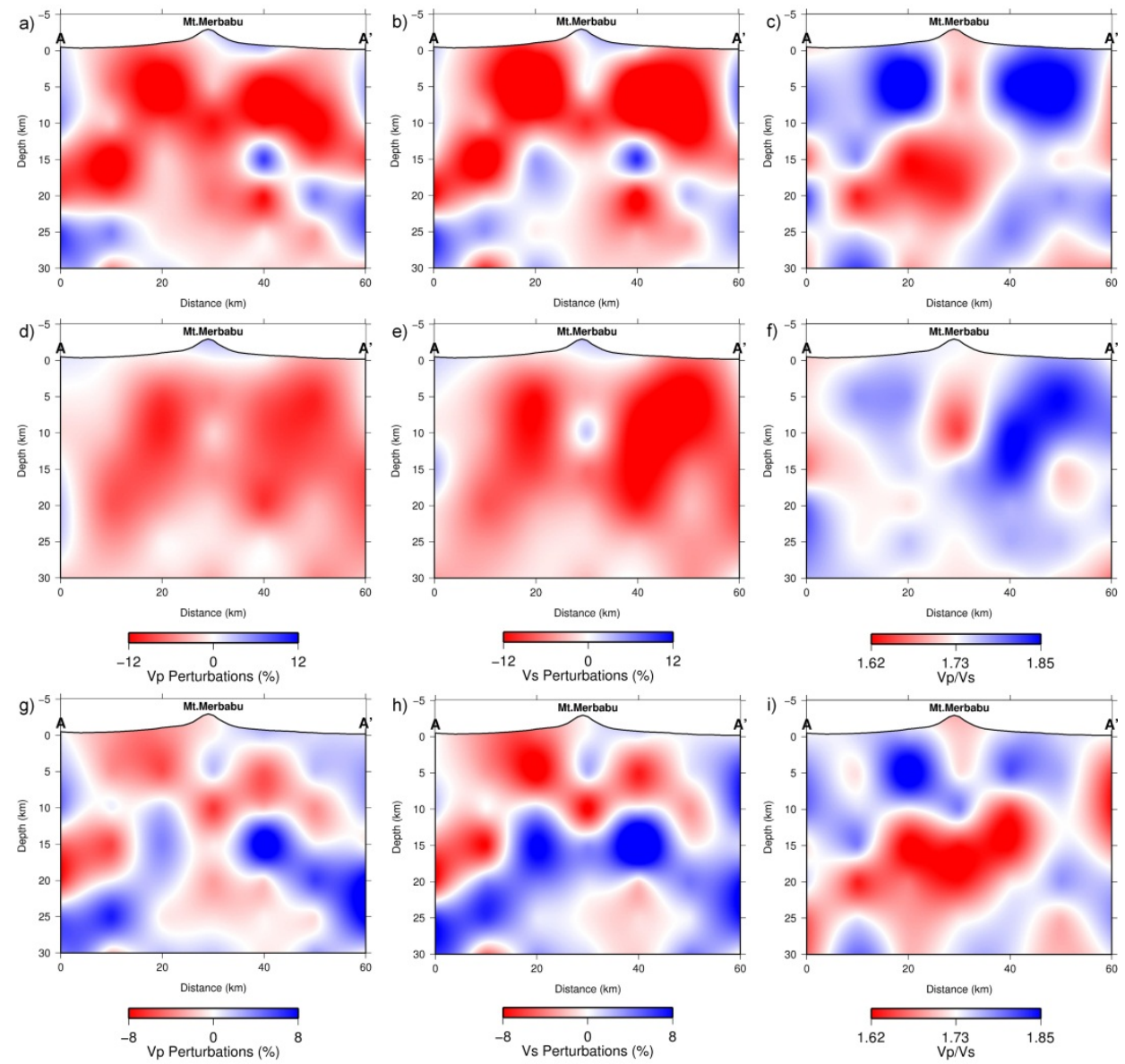

513Fig. 4. West-east (A-A') vertical sections across Mt. Merbabu through a) Vp, b) $514 \mathrm{Vs}$, and $\mathrm{c}$ ) $\mathrm{Vp} / \mathrm{Vs}$ models from joint inversions using the full data set (from 515DOMERAPI, MERAMEX, BMKG, and BPPTKG); d-f) similar to a-c, but 516without the DOMERAPI data; and g-i) the difference between a-c and d-f plotted 517 with a more restricted perturbation scale $( \pm 8 \%)$ to illustrate the improvement due 518to the inclusion of DOMERAPI data. Note that depth $=0 \mathrm{~km}$ depicts MSL. 

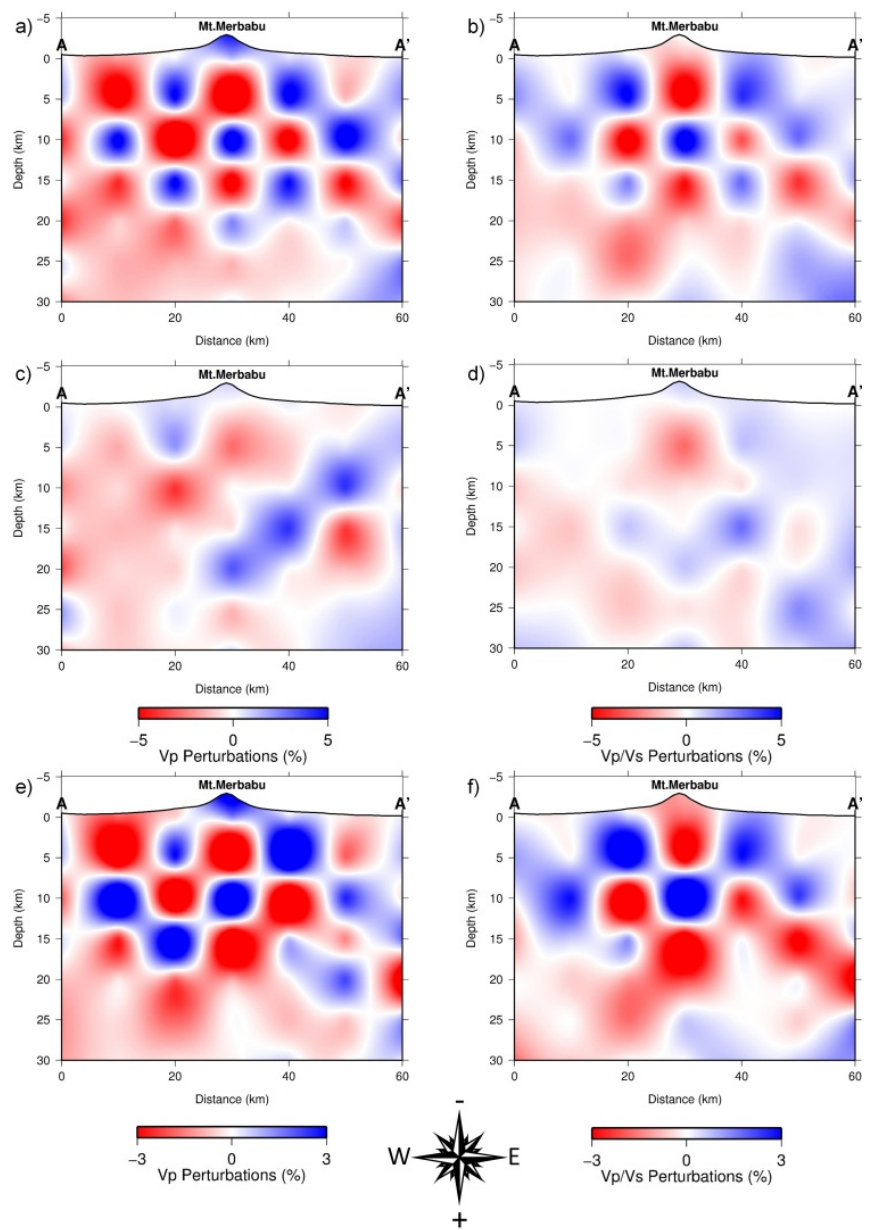

519

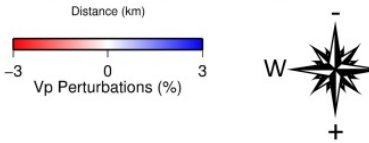

520Fig. 5. Results of the checkerboard test for vertical sections $A-A^{\prime}$. a) Vp and b) $521 \mathrm{Vp} / \mathrm{Vs}$ from joint inversions using the full data set; $\mathrm{c}-\mathrm{d}$ ) similar to $\mathrm{a}-\mathrm{b}$, but without 522the DOMERAPI data; e-f) the difference between $a$ and $c$, and $b$ and $d$, 523respectively. Note that the checkerboard recovery of Vs is similar to the one for $524 \mathrm{Vp} / \mathrm{Vs}$. 

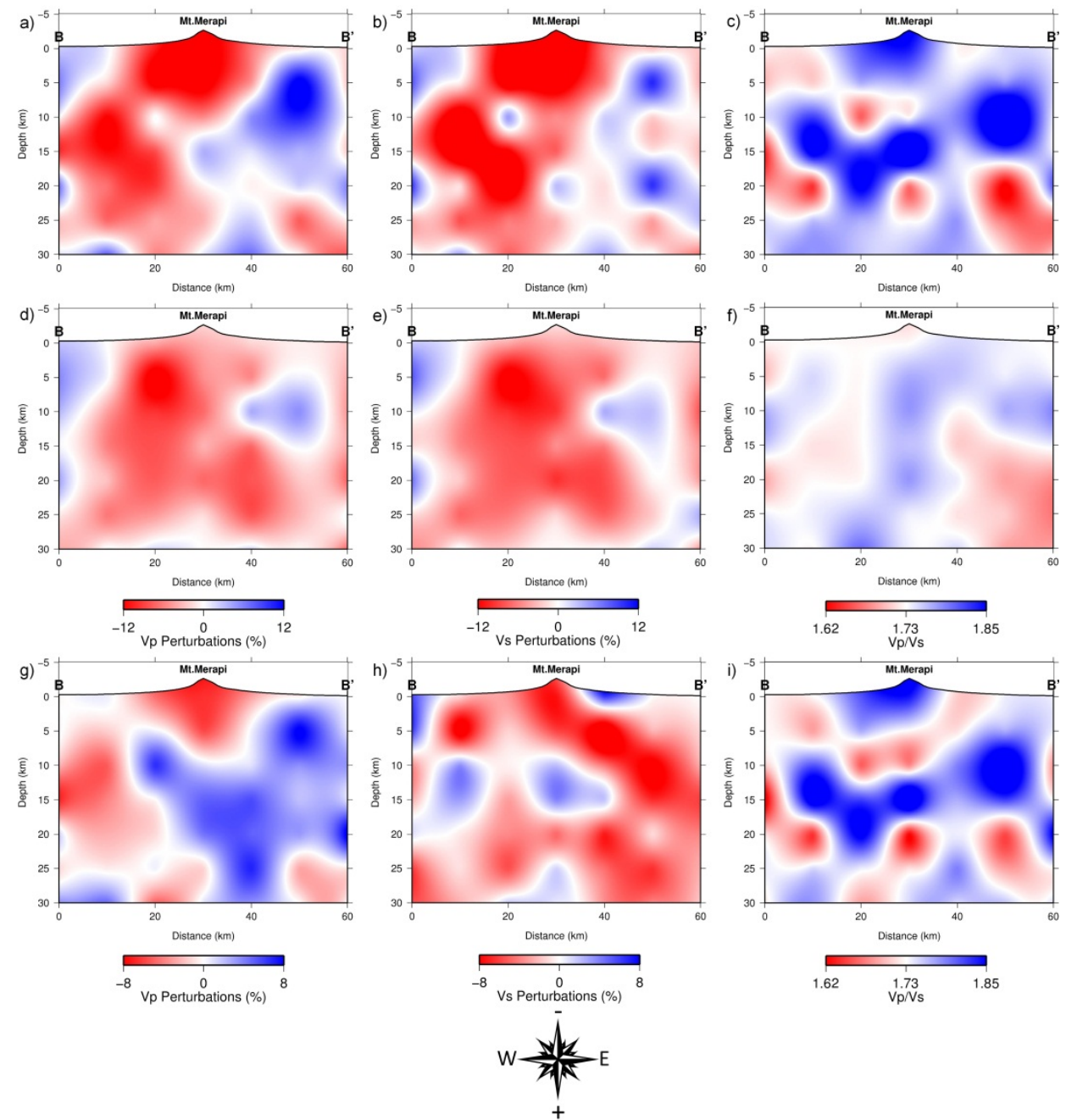

526

527Fig. 6. Same as Fig. 4, except for west-east (B-B') vertical sections across Mt.

528Merapi. 

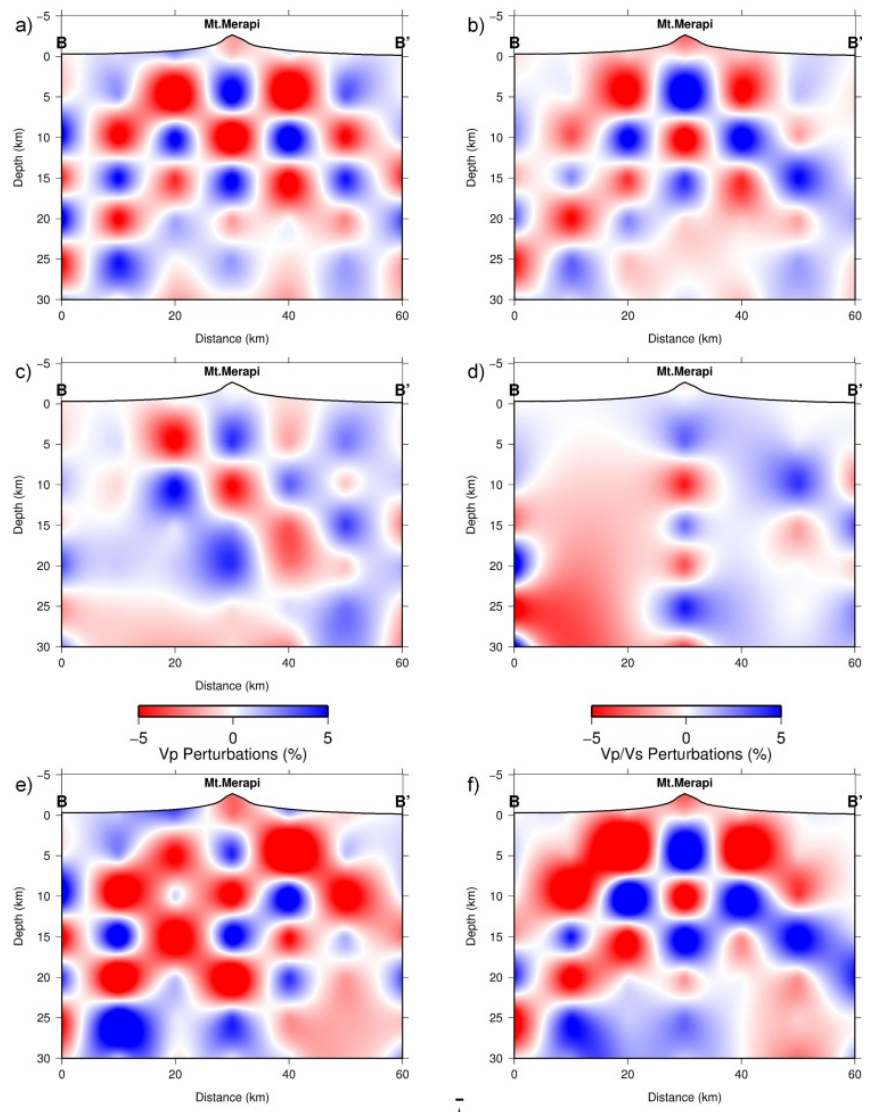

530

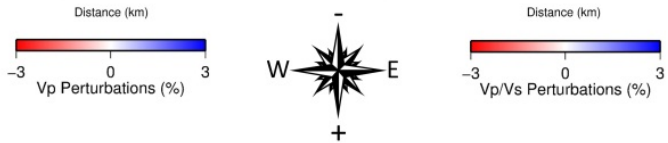

531Fig. 7. Same as Fig. 5, except for B-B' vertical sections across Mt. Merapi. 


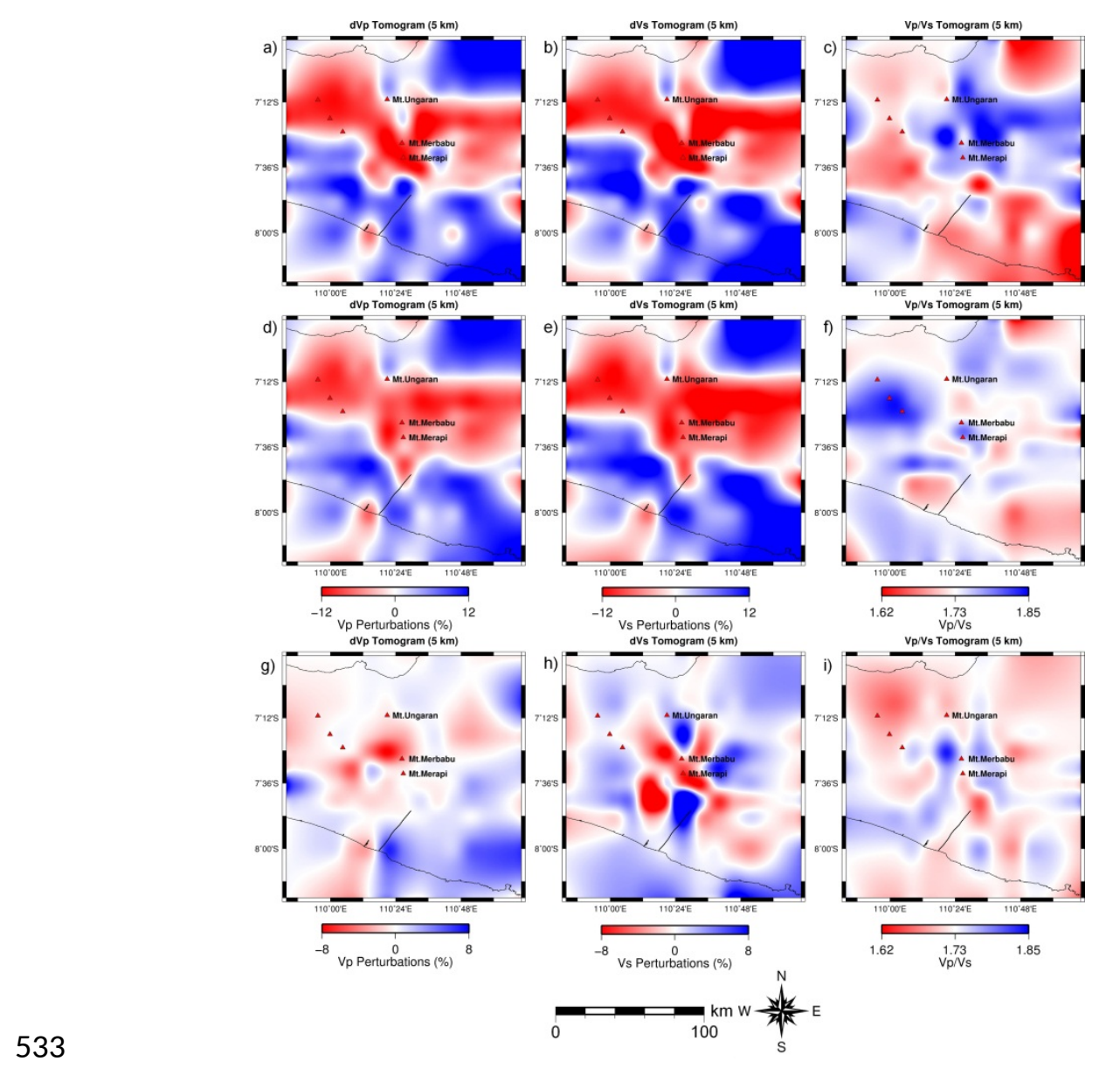

534Fig. 8. Horizontal slices at $5 \mathrm{~km}$ depth below MSL through a) Vp, b) Vs, and c) $535 \mathrm{Vp} / \mathrm{Vs}$ models from joint inversions using the full data set; $\mathrm{d}-\mathrm{f}$ ) similar to a-c, but 536without the DOMERAPI data; g-i) the difference between a-c and d-f plotted with 537a more restricted perturbation scale $( \pm 8 \%)$ to demonstrate the improvement due to 538the inclusion of DOMERAPI data. 


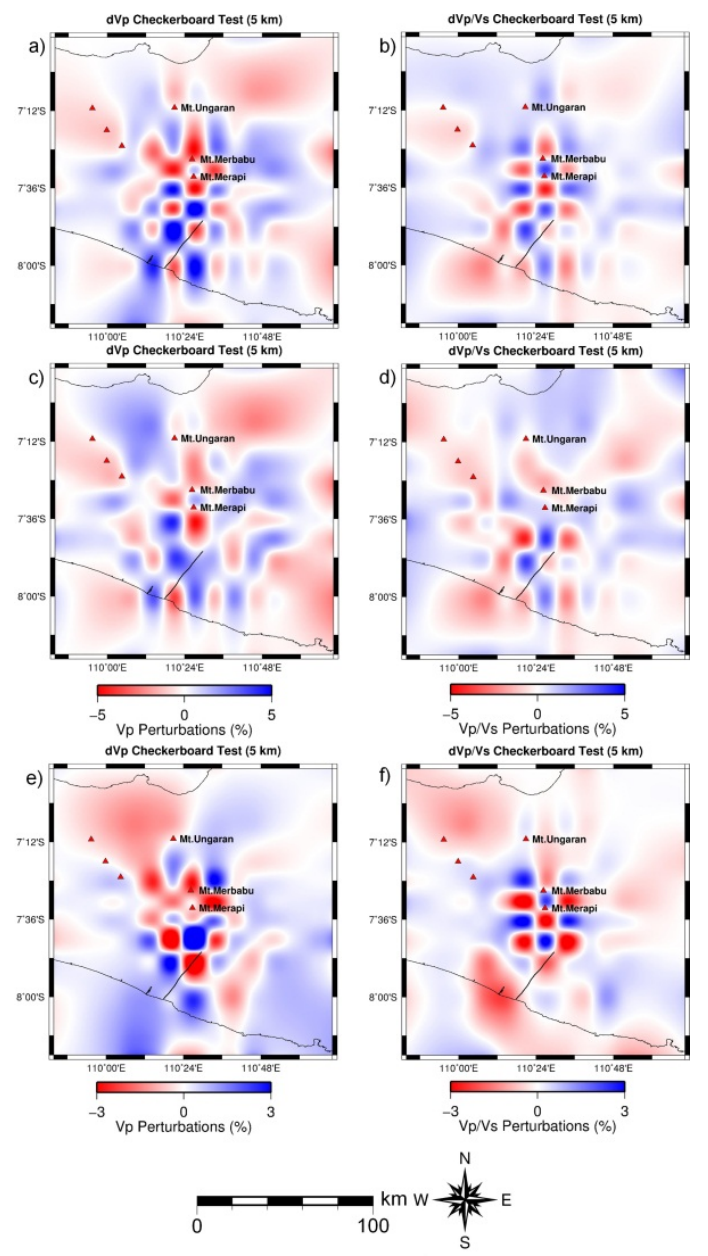

541Fig. 9. Results of the checkerboard test for horizontal slices at $5 \mathrm{~km}$ depth. a) $\mathrm{Vp}$ 542and b) Vp/Vs from joint inversions using the full data set; c-d) similar to $a-b$, but 543without the DOMERAPI data; e-f) the difference between a and c, and b and d, 544respectively. Note that the checkerboard recovery of Vs is similar to the one for $545 \mathrm{Vp} / \mathrm{Vs}$. 